\title{
Production of medusae buds by the polyps of Ratbkea octopunctata (M. Sars) (Hydroida Athecata)
}

\author{
Jean Bouillon and Bernhard Werner \\ Laboratoire d'Anatomie Comparée et de Microscopie Electronique, \\ Université libre de Bruxelles
}

Biologische Anstalt Helgoland, Zentrale, Hamburg-Altona

EXTRAIT: Le bourgeonnement médusaire des polypes de Ratbkea octopunctata (M. Sars) (Hydroida Athecata). L'organogénèse du bourgeonnement médusaire polypodial est étudié chez Rathkea octopunctata et comparé avec celui du bourgeonnement médusaire manubrial de la même espèce. A l'encontre de ce dernier exclusivement ectodermique, le bourgeonnement des polypes s'effectue à partir des feuillets constitutifs ectodermiques et endodermiques de l'organisme souche.

\section{INTRODUCTION}

Its has been known since the works of CHUN (1895) and BRAEM (1908) that manubrial medusa buds of Ratbkea octopunctata are not formed by the two constituting layers of the maternal organism, as in other hydroids, but exclusively by the ectoderm. Such a method of budding has been vigorously discussed; whether or not it occurs has been a subject of controversy for a long time. Because of such disagreement one of us (Boullion 1961) decided to review this type of budding. The results of this research fully confirm and clarify the observations made both by CHUN and BraEM.

Exclusively ectodermal budding, remarkable as it is, appears to be rather exceptional; it is actually known in only four species of Anthomedusae belonging to three families of "Filifera": Ratbkea octopunctata (M. SARs), family Rathkeidae, after CHUN (1895); Lizzia blondina (Forbes), family Bougainvilliidae, after CHun (1895); Bongainvillia niobe (MAYER), family Bougainvilliidae, after MAYER (1910); Podocoryne minima (TRINCI), family Hydractiniidae, after TrINCr (1903). Among these four forms only the polyps of Ratbkea octopunctata are sufficiently well known to be studied with confidence. Thus, it seemed interesting to determine whether medusae produced by the polyp phase have the same origin (ectoderm only) as those produced by the medusae phase, or whether they originate in the classic didermic manner. This is the aim of the work presented in this paper.

The hydranths of Ratbkea octopunctata were described for the first time by 
REES \& Russelt in 1937, who reared them from planula larvae produced by a culture of medusae captured in the plankton of Plymouth, England.

WERner $(1956,1958)$ was the first author to observe medusae budding on these polyps. He experimentally induced their appearance by subjecting colonies of Ratbkea octopunctata to variations in temperature. At a temperature lower than $14^{\circ}$ to $12^{\circ} \mathrm{C}$ medusae buds appear, very numerous and localized principally at the level where the stolons form a branching network. Occasionally they also appear at the bases of the hydranths.

The budding colonies which appeared in WERNER's cultures were fixed in Bouin's solution. Different characteristic stages of medusae buds were selected and sectioned at six microns. The sections thus obtained were stained by a trichrome technique involving hematoxylin, phloxin and light green. The drawings illustrating the present paper are the work of Madame Dorzé, to whom we are heartily indebted.

\section{ORGANOGENESIS OF MEDUSAE BUDS}

\section{Formation of a blastogenic outpushing}

The first indication of medusa bud differentiation in a Ratbkea octopunctata polyp consists of an evagination of the stolon wall. The two layers, ectodermal and endodermal, of the stolon participate in this outpushing. A didermic "hernia" is thus produced which contains a diverticulum from the digestive cavity of the stolon. The ectoderm and endoderm are composed of cells typically found in the stolon region. The ectoderm is formed of flattened epithelio-muscular cells, vacuolated and clear, with large nuclei and clearly visible nucleoli. Among these cells some elements are present which contain a much smaller nucleus (Fig. $6 \mathrm{~A}, \mathrm{~B}$ ) and in most cases a vesicle in the cytoplasm; these are cnidoblast cells. The endoderm is composed of absorbent cells, rich in digestive and excretory inclusions, and some gland cells of the "spheruleuses stomacales" type (Bounlon 1963).

The blastogenic evagination soon forms a peduncle and becomes club-shaped (Fig. 1). Only the apical portion, limited to the distal part of the club, participates in true blastogenesis. It is in this limited zone that the ectodermal and endodermal cells undergo profound structural modifications which take them back to the state of embryonic cells. This is the phenomenon of morphallaxis observed already in budding of other hydroids (BRIEN 1942, BOUILLON 1955, 1956).

The ectoderm of the blastogenic region is devoid of so-called interstitial cells. The only basophilic elements which could have been confused with them contain a vacuole and appear destined to become functional cnidoblasts. No matter what the significance of these latter elements, strongly characterized by their small cytoplasmic and nuclear volumes, they do not in any way intervene in the formation of the medusa bud.

The ectodermal epithelio-muscular cells of the apical region which participate in bud formation become longer and lose their vacuolated aspect. Their cytoplasm condenses and they become rich in RNA. The nuclei of these cells enlarge and stain more intensely. The nucleoli also acquire a larger volume (Fig. 1). These ectoblastic cells 


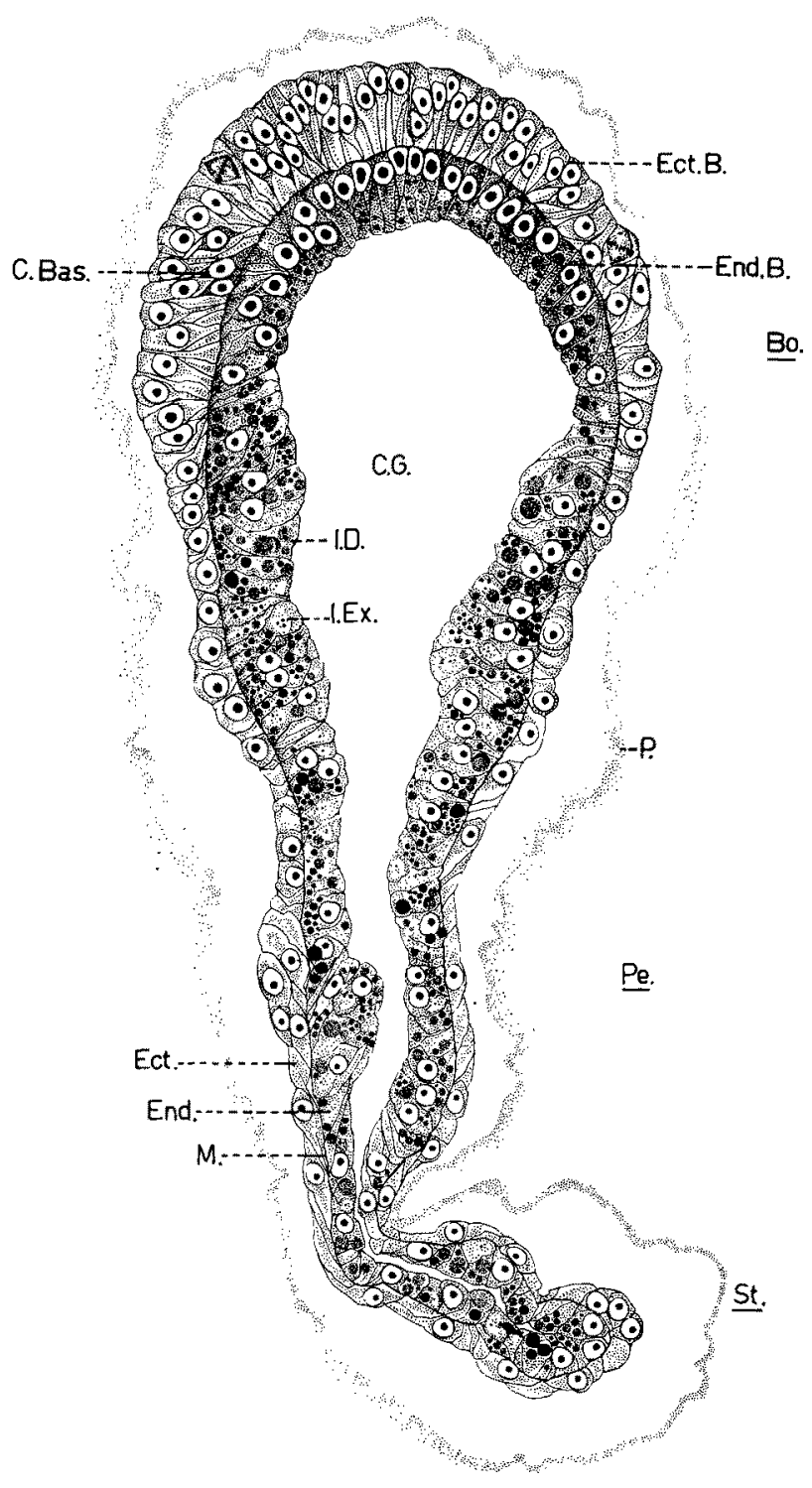

Fig. 1: Blastogenic evagination (didermic) from the stolon of a Rathkea octopunctata colony. This represents the first stage in medusa bud formation. Bo. medusa bud, C. Bas. basophilic cell, C. G. gastric cavity, Ect. ectoderm, Ect. B. blastogenic ectoderm, End. endoderm, End. B. blastogenic endoderm, $I . D$. digestive inclusions, $I . E x$. excretory inclusions, $M$. mesoglea, $P$. perisarc, $P e$, blastogenic peduncle, $S t$, stolon 
begin to divide rapidly; the apical ectoderm thickens and soon becomes stratified (Figs. 1, 2).

The modifications undergone by the endodermal cells participating in blastogenesis are even more pronounced and spectacular. These cells lose their numerous digestive and excretory inclusions. Their size becomes reduced, their cytoplasm more dense and they become richer in RNA. The nuclei of these cells also stain more intensely, and especially noticable is the considerable increase in size of the nucleoli (Fig. 1).

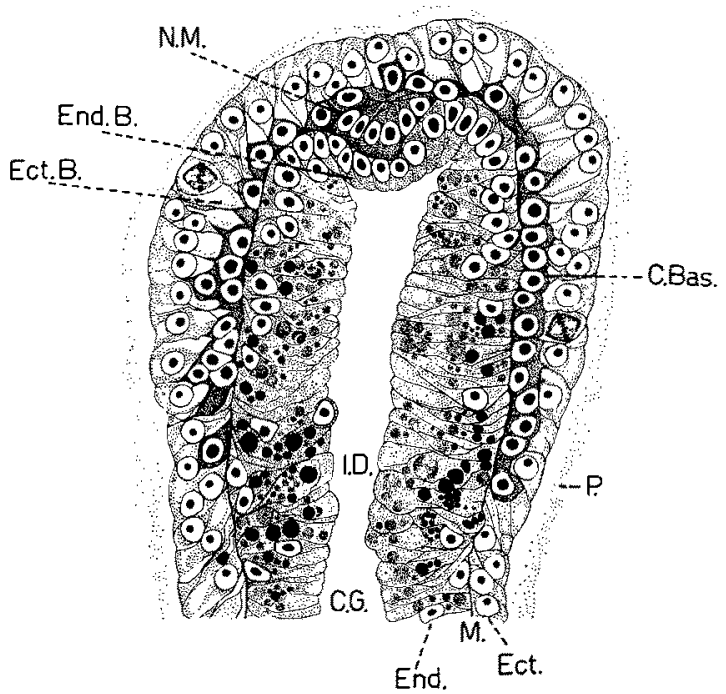

Fig. 2: Formation of the medusa nodule by proliferation of ectoblastic cells and appearance, in outline, of the small endoblastic cup formed by dedifferentiated endoderm. C. Bas, basophilic cell, C. G. gastric cavity, Ect. ectoderm, Ect. B. blastogenic ectoderm, End. endoderm, End. B. blastogenic endoderm, $I . D$. digestive inclusions, $M$. mesoglea, $N . M$. medusa nodule, $P$. perisarc

\section{Formation of the entocodon}

The apical ectoderm of the medusa bud, as we have seen, divides rapidly and becomes manywlayered. Certain of the cells thus formed are distinguishable from others in the area. They exhibit cytoplasmic condensation, which results in increased basophilia, and larger nucleoli (Fig. 2 C.Bas.). These cells appear to undergo still more intense changes, and they acquire "embryonic" characteristics more pronounced than the adjacent ectoblastic cells. They differ from the latter in yet an other aspect; all are connected directly to the mesoglea (Fig. 2 C. Bas.). The destiny of these cells seems fixed; they move along the mesoglea layer and condense in the apical region under the unspecialized peripheral ectoblastic cells to form a massive button, the entocodon (Fig. 2 N.M.).

The entocodon, also called medusa nodule, or "glodkenkern", is one of the most characteristic and important structures participating in the process of medusa budding. 


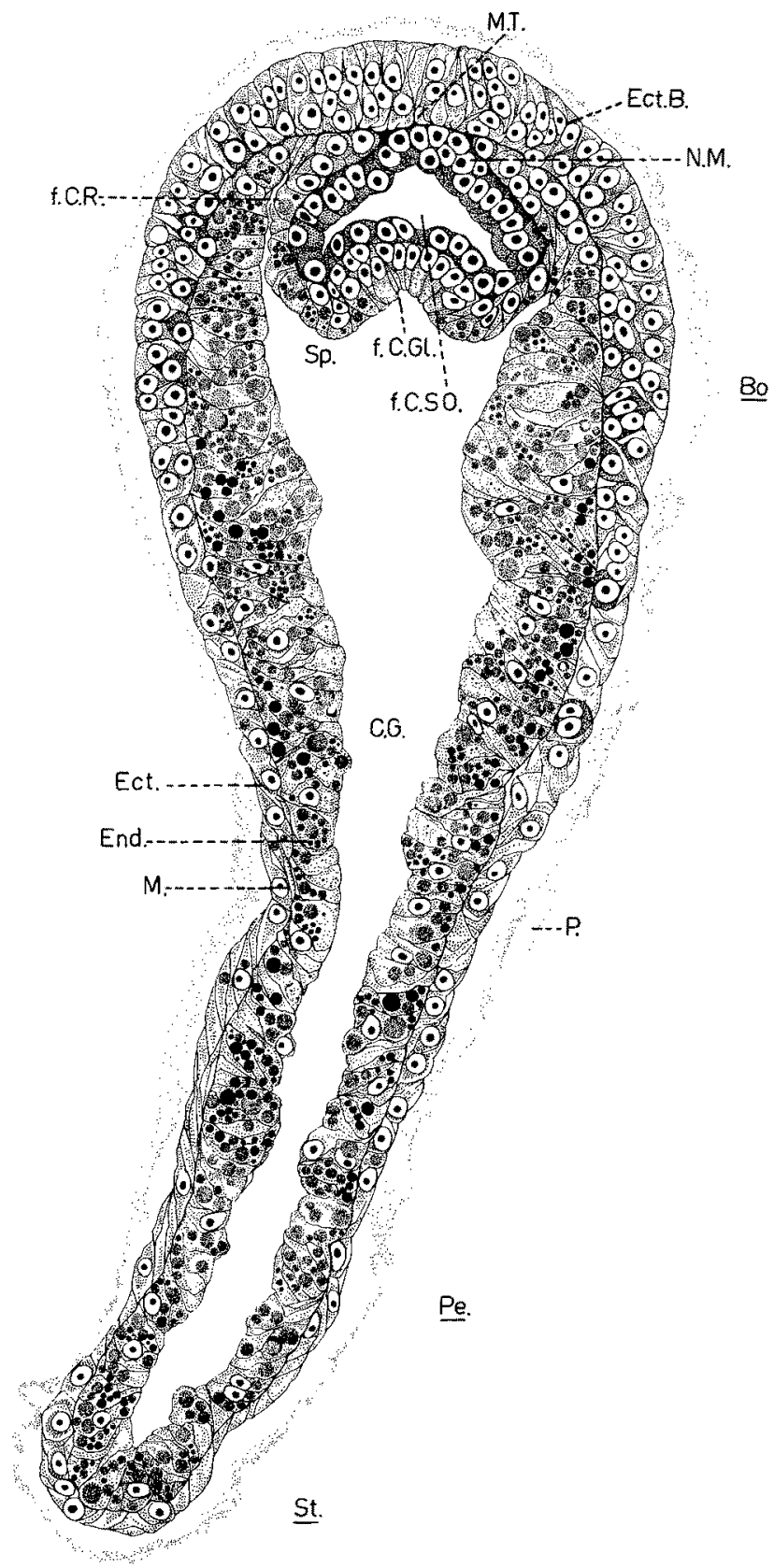

Fig. 3: More advanced stage in which the medusa nodule is hollowed into a cavity, the future sub-umbrellar cavity (f.C.S.O.). The tentacle mass (M.T.) is ready to erupt, and the outlines of the future radial canals (f.C.R.) and manubrium $(S p$.) are visible. Bo. bud, $C$. G. gastric cavity, Ect. ectoderm, Ect. B. blastogenic ectoderm, End. endoderm, $f . C$. Gl. future gland cells, $f$. C. $R$. future radial canals, f. C. S. O. future sub-umbrellar cavity, $M$. mesoglea, $M$. T. tentacle mass. $N, M$. medusa nodule, $P$. perisarc, $P e$. peduncle of bud, $S p$. spadix, $S t$. stolon region 
It seems to possess the power of an organizer, or inducer, during the course of the budding process, as has been demonstrated experimentally by REISINGER (1957). Cells of the entocodon also give rise, during the course of development, to highly differentiated tissues:

(1) subumbrellar ectoderm supplied with striated muscle fibers,

(2) internal ectoderm of the velum which possesses the same type of fibers, and

(3) manubrial ectoderm, in the midst of which sexual and blastogenic elements arise.

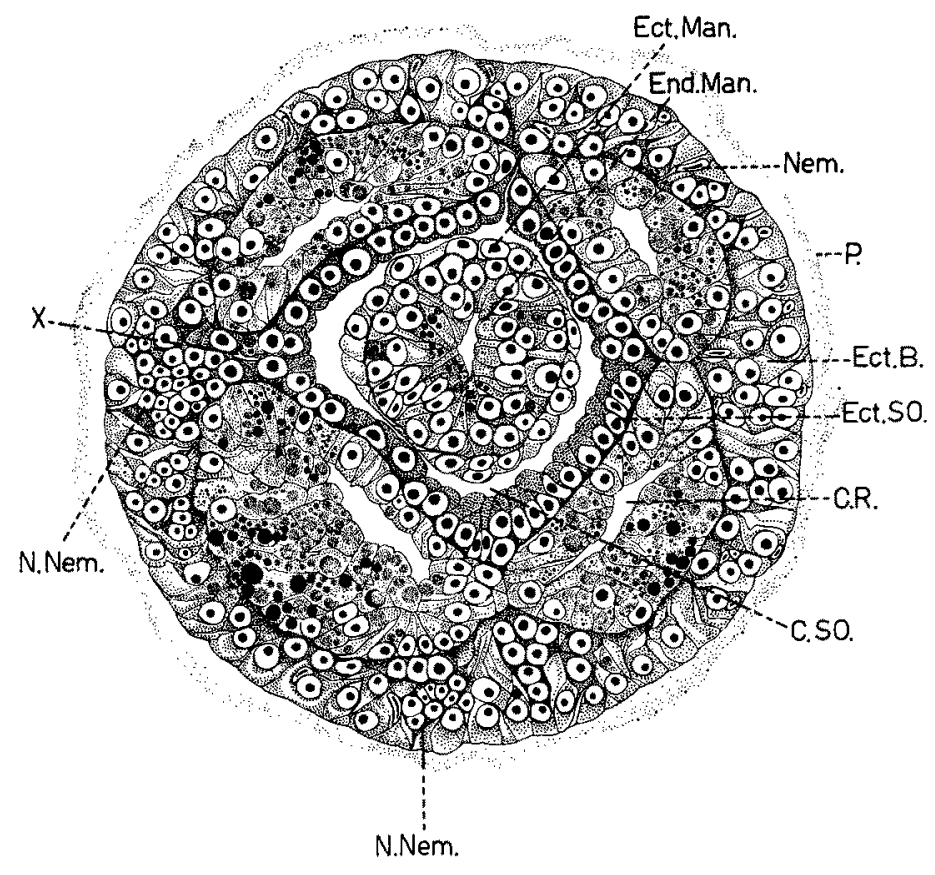

Fig. 4: Transverse section of a medusa bud at the level of the sub-umbrellar cavity. The medusa bud is slightly older than the one represented in Figure 3. C. R. radial canals, C. SO. sub-umbrellar cavity, Ect. B. blastogenic ectoderm, Ect. Man. manubrial ectoderm, Ect. SO. sub-umbrellar ectoderm, End. Man. manubrial endoderm, $N$. Nem. nest of nematoblasts, $P$. perisarc, $X$. separation between the outlines of the radial canals

\section{Formation of sub-umbrellar cavity and outlines of the gastro-vascular canals}

The entocodon is at first compact and solid but very soon hollows out to form a cavity, the future sub-umbrellar cavity (Fig. 3). This structure is interposed between the stratified apical ectoderm from which it is separated, and the tissues of the gastric cavity which it pushes back. The apical endoblast of the gastric cavity, thus depressed, assumes the aspect of a small cup surrounding the base of the entocodon (Figs. 2, 3). This small endoblastic cup sends out four didermic masses distally separated from each 


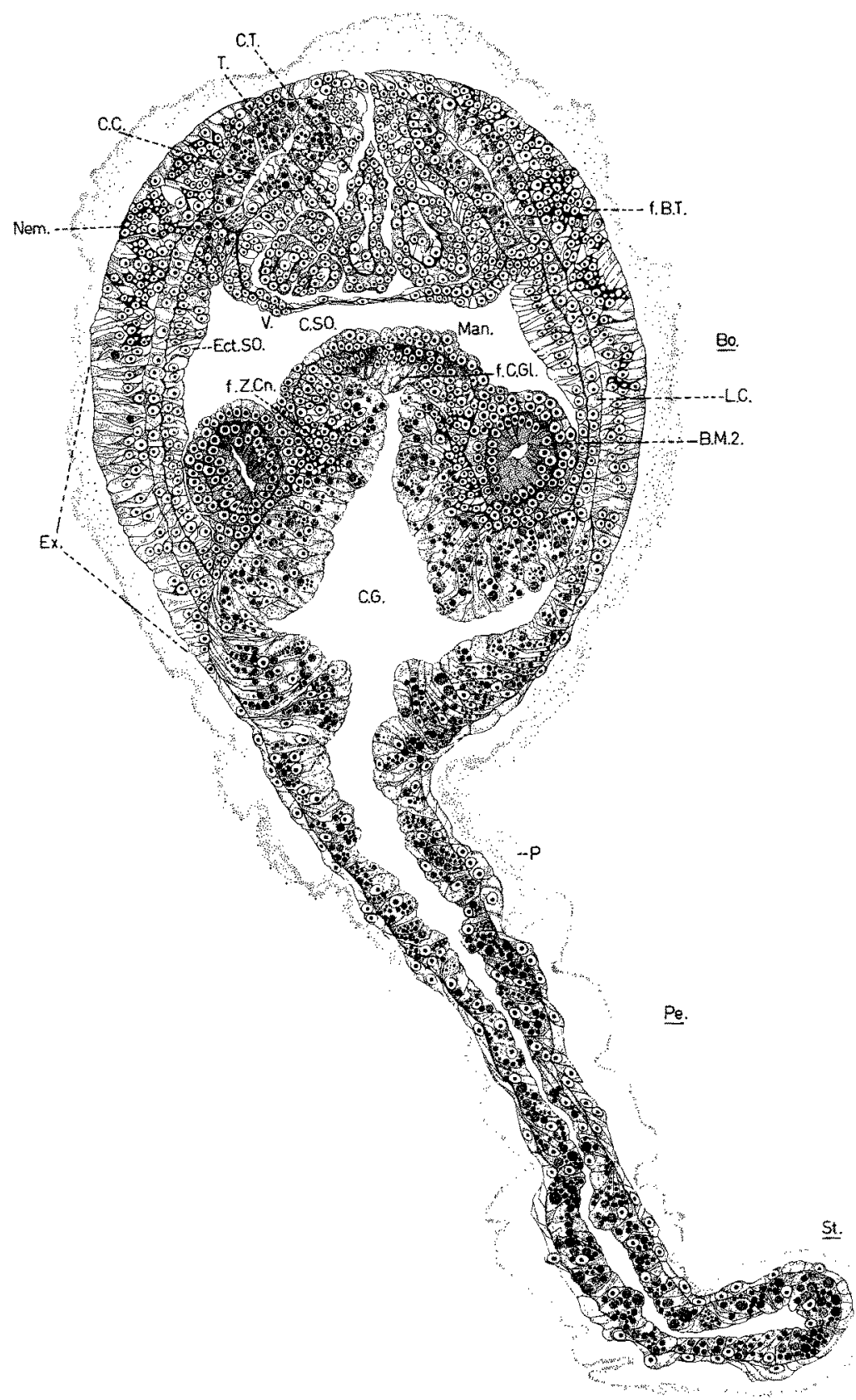

Fig. 5: Medusa bud ready to detach from colony of parental polyps. It is possible to observe already the presence of a new generation of buds at the level of the manubrial budding zone of the young medusa; these buds are formed solely by ectoderm. B. M. 2. second generation bud, Bo. medusa bud, C. C. circular canal, C. G. gastric cavity, C. SO. sub-umbrellar cavity, C. T. tentacle cavity, Ect. SO sub-umbrellar ectoderm, Ex. exumbrella, $f . B, T$. future tentacle bulb, $f . C$. Gl. future gland cells, $f . Z$. Cn. future cnidoblast zone, $L$. C. gastrodermal lamella, Man. manubrium, Nem. nematoblasts, $P$. perisarc, Pe. peduncle of medusa bud, St. stolon, $T$. tentacles, $V$. velum 
other and in the form of a cross (Fig. $4, X$ ). These masses correspond to the primordia of the radial canals (Figs. 3 f. C.R. and 4 C.R.). Subsequently, as the bud grows they become further separated from each other but remain in contact by a strip of singlelayered endoderm, the gastrodermal lamella (Fig. 5 L.C.). The apex of the endoblastic cavity forms a median diverticulum which pushes back the ectodermal plate of the subumbrellar cavity and lines it; this is the spadix or future manubrium (Figs. 3, 5).

\section{Tentacular cavity, velum, final steps of organogenesis}

After the sub-umbrellar cavity, radial canals and manubrium are formed, the apical ectoderm of the bud thickens a second time to form a new mass, in the midst of which differentiates a third cavity, the tentacular cavity (Boullon 1955, 1956, 1961). The outlines of the first tentacles and the velum appear in the interior of this structure (Fig. $5 T$. and $V$.). The first tentacles arise as extensions of the radial canals. At the extremity of these canals the first indices of tentacular bulbs appear, rich in nematoblasts (Fig. 5 f. B.T. and Nem.). The other tentacles do not form until later, by expansion of the circular canal which has been formed in the meantime by fusion of the distal extremities of the four radial canals (Fig. 5 C.C.).

The endodermal layer of the manubrium contains numerous digestive inclusions which originated in the parental endoderm. Numerous nematoblasts develop in the area (Fig. 5 f.Z.Cn.), indicating the location of the future cnidoblast zone of the young medusa (Bounlon 1956, 1961). Glandular elements differentiate in the region corresponding to the mouth opening (Fig. 5 f. C. Gl.).

The principal organs of the medusa thus develop in the same manner as described for other species (Boullon 1956). The young medusa is then ready to detach from its peduncle, although it is still surrounded by a thin peridermal envelope. This latter covering, however, has lost its former consistency (Fig. 5 P.).

The mouth does not perforate the summit of the manubrium until a later stage of medusa development. However, well in advance of this event and even before liberation of the young medusa it is already possible to distinguish in its manubrium, at the level of the future budding zone (Boulloon 1961), the formation of new medusa buds (Fig. 5 B.M. 2). Contrary to the origin of the initial medusa bud those of the second generation, called secondary medusae, do not arise from the two layers constituting the primary initial bud, but instead exclusively from manubrial ectoderm. In all details the processes involved in this secondary budding are comparable to those described previously for manubrial budding of the Ratbkea octopunctata (Fig. 7 A, B after Boullion 1961).

Thus, even before the young medusa bud is entirely formed and before it is liberated from the parent, its cells have acquired appropriate medusa characteristics, transmissible asexually from medusa to medusa (somatic mutation?) and different from those of the parent organism.

The possibility, in Ratbkea octopunctata, of forming new medusae from ectodermal cells is an exclusive property of cells of the medusa phase. Medusa buds form on the polyp according to classic procedures, from the two layers which constitute all 

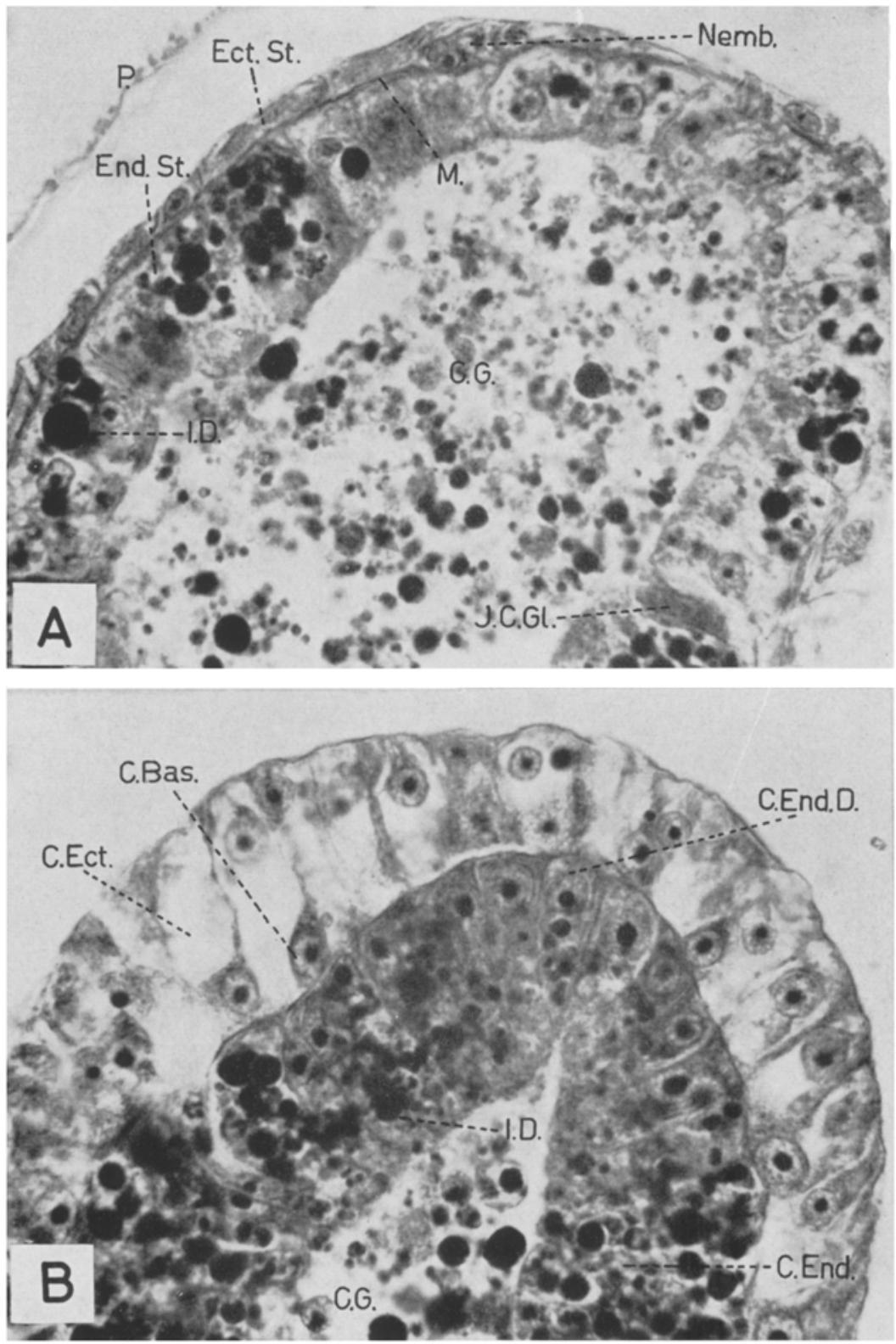

Fig. 6A: Transverse section of Rathkea octopunctata at the stolon level of the polyp. C. G. gastric cavity, Ect. St. ectoderm of the stolon, End. St. endoderm of the stolon, $l$. D. digestive inclusions, $J$. C. Gl. young gland cells, $M$. mesoglea, Nemb. nematoblasts, $P$. perisarc

Fig. 6B: Initial step in the differentiation of a blastogenic "hernia", which arises from a stolon of Rathkea octopunctata. C. Bas. basophilic cell, C. Ect. epithelio-muscular cells in the process of dedifferentiation, C. End. absorbent endodermal cells, C. End. D. absorbent endodermal cells in the process of dedifferentiation, $C . G$. gastric cavity, $I . D$. digestive inclusions. 
hydroids. Therefore, depending on whether it is the polyp or medusa phase which is involved, formation of medusa buds can be accomplished by two very dissimilar modes. The existence of these two modes demonstrates the degree of specialization and divergence which can exist in the two phases of a single hydroid species.

In the last few years several authors have obtained reorganization and formation of a normal hydroïd from a portion of one of the two constituting layers (ZwILLING 1958,1963 , Haynes \& Burnet't 1963, Diehl 1965). Such a phenomenon occurs normally in nature during the manubrial medusa budding of the medusae of Ratbkea octopunctata, Bougainvillia niobe, Lizzia blondina and Podocoryne minima and raises again the question of significance and value of the endodermal and ectodermal layers.

\section{SUMMARY}

1. The formation of medusa buds on the polyps of Ratbkea octopunctata is studied and compared with budding of medusae from the manubrium of the same species.

2. In contrast to the latter, which is exclusively ectodermic, medusa budding of polyps involves both the ectodermal and endodermal layers comprising the parent organism.

\section{LITERATURE CITED}

Boulllon, J., 1955. Le bourgeonnement manubrial de la méduse Limnocnida tanganyicae. Bull. Acad. r. Sci. colon. N.S. 1, 1152-1180.

- 1957. Etude monographique du genre Limnocnida (Limnoméduses). Annls Soc. r. zool. Belg. 87, 254-500.

- 1961. Sur le bourgeonnement médusaire manubrial de Ratbkea octopunctata. Annls Soc. r. zool. Belg. 92, 7-25.

- 1963. Les cellules glandulaires des Hydroides. C. $r$. hebd. Séanc. Acad. Sci., Paris 256, $1617-1620$.

Braem, P., 1908. Die Knospung der Margeliden, ein Bindeglicd zwischen geschlechtlicher und ungeschlechtlicher Fortpflanzung. Biol. Zbl. 28, 790-798.

Brien, P., 1942. Etude sur deux Hydroides gymnoblastiques: Cladonema radiatum et Clava squamata. Mém. Acad. r. Belg. Cl. Sci. 80 20, 1-116.

Chun, C., 1896. Atlantis, Biologische Studien über pelagische Organismen. 1. Die Knospungsgesetze der proliferierenden Medusen. Zoologica, Stuttg. 7 (19), 1-51.

DiełL, F., 1965. Unpublished observations.

Haynes, J. \& BurnetT, A., 1963. Dedifferentiation and redifferentiation of cells in Hydra viridis. Science, N.Y. 142, 1481-1483.

Mayer, A., 1910. Medusae of the world. Publs Carnegie Instn 109.

Rees, W. \& Russell, F., 1937. On rearing the hydroids of certain medusae, with an account of the methods used. J. mar. biol. Ass. U. K. 22, 61-82.

ReIsINGER, E., 1957. Zur Entwicklungsgeschichte und Entwicklungsmechanik von Craspedacusta (Hydrozoa, Limnotrachylina). Z. Morph. Ökol. Tiere 45, 656-698.

Trinci, G., 1903. Di una nuova specie di Cytaeis gemmante del Golfo di Napoli. Mitt. zool. Stn Neapel 16, 1-34.

- 1904. Notizie sulla gemmazione della "Dysmorphosa minuta“ A.G. Mayer e sulla biologia delle Margellidae in generale. Monitore zool. ital. 15, 304-310.

Werner, B., 1956. Über die entwicklungsphysiologische Bedeutung des Fortpflanzungswechsels der Anthomeduse Ratbkea octopunctata M. Sars. Zool. Anz. 156, 159-177. 

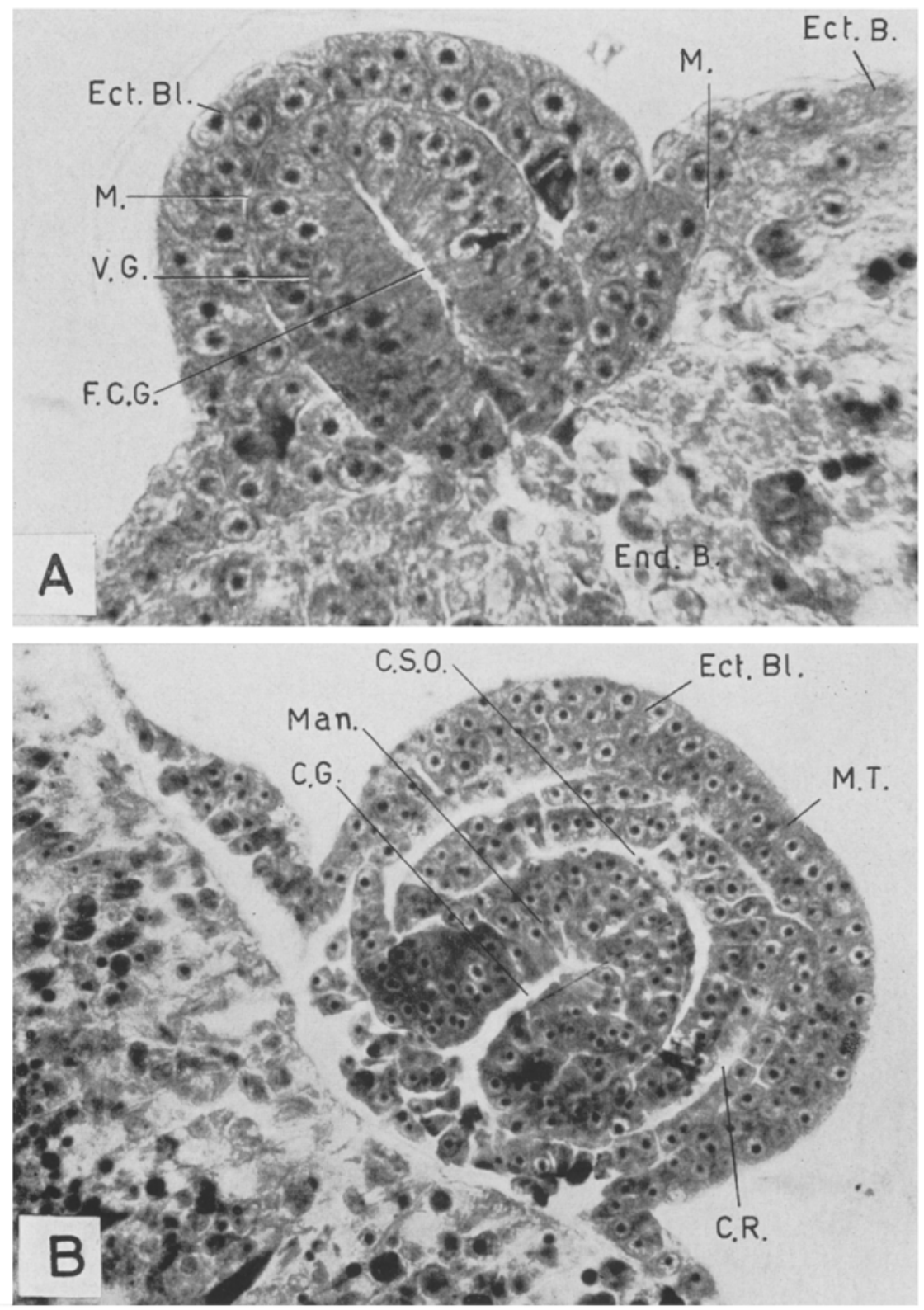

Fig. 7: Two developmental stages of a manubrial medusa bud of the medusa of Ratbkea octopunctata, after Boulloon 1961, Planche I, Fig. A, B. A: Composition of the central gastric vesicle. This vesicle will give rise to all structures which are derived from endoderm in the classic (didermic) type of budding. Ect. B. blastogenic ectoderm, Ect. Bl. ectoblasts, End. B. blastogenic endoderm, $F . C$. G. future gastric cavity, $M$. mesoglea, V. G. gastric vesicle. $B$ : Bud at a more advanced stage; manubrium, gastric cavity, sub-umbrellar cavity, velum and tentacle mass are easily distinguished. Such a bud arising exclusively from ectoderm is always isolated; its gastric cavity is no longer connected to the manubrial cavity of the parent medusa. C. G. gastric cavity, C. S. O sub-umbrellar cavity, C. R. radial canals, Ect. Bl. ectoblasts, Man. manubrium, $M . T$, tentacle mass 
- 1958. Dic Verbreitung und das jahreszeitliche Auftreten der Anthomeduse Ratbkea octopunctata M. Sars, sowie die Temperaturabhängigkeit ihrer Entwicklung und Fortpflanzung. Helgol. Wiss. Meeresunters, 6, 137-170.

- 1963. Experimentelle Beobachtungen über die Wirksamkeit von Außenfaktoren in der Entwicklung der Hydrozoen und Etörterung threr Bedeutung für die Evolution. Veröff. Inst. Meeresforsch. Bremerh. Sonderbd. 3. Meeresbiol. Symp., 153-177.

ZWILLING, E., 1958. Complete reconstitution from ectoderm in Cordylophora. Biol. Bull. mar. biol. Lab., Woods Hole 115, 319.

- 1963. Formation of endoderm from ectoderm in Cordylophora. Biol. Bull. mar. biol. Lab., Woods Hole 124. 367-378. 